\title{
Risk management of risk management: Combining proton pump inhibitors with low-dose aspirin
}

This article was published in the following Dove Press journal:

Drug, Healthcare and Patient Safety

5 October 2010

Number of times this article has been viewed

\section{Harald Vonkeman \\ Inger Meek \\ Mart van de Laar}

Department of Rheumatology and Clinical Immunology, Arthritis Centre Twente, Medisch Spectrum Twente and University of Twente, Enschede, The Netherlands
Corresspondence: Harald Vonkeman Dept. of Rheumatology and Clinical Immunology, Arthritis Centre Twente, Medical Spectrum Twente, Arensplein I, 75II JX Enschede, The Netherlands Email h.vonkeman@mst.nl

\begin{abstract}
Low-dose aspirin is widely used in the primary and secondary prevention of cardiovascular events, but is associated with a range of upper gastrointestinal side effects. In this review, we summarize the rationale for low-dose aspirin therapy, quantify the risk for upper gastrointestinal side effects, identify the risk factors involved, and provide an overview of preventive strategies, thereby focusing on the rationale and clinical utility of combining proton-pump inhibitors with low-dose aspirin.
\end{abstract}

Keywords: low-dose aspirin, gastrointestinal ulcers, Helicobacter pylori, proton-pump inhibitors, $\mathrm{H}_{2}$-receptor antagonists, clopidogrel

\section{Introduction}

The use of aspirin-like compounds predates the dawn of modern medicine. The earliest known references to the medicinal use of myrtle and willow tree bark, original sources of salacin (named after its source Salix alba, the White Willow) can be traced back to the ancient Egyptians. The application of willow tree bark for stiff and painful joints is recommended in Ebers Papyrus, a medical text dated to the reign of Amenhotep I, around 1534 BC. Hippocrates of Cos (460-377 BC) who spent several years in Egypt studying medicine, also noted that chewing the bitter leaves of the willow tree reduced pain. ${ }^{1-4}$ In 1899 Felix Hoffmann, a chemist working for the Bayer company, perfected the formula for acetylating salicylic acid to make it less bitter and less gastrotoxic. Acetylsalicylic acid, the world's first truly synthetic and eventually most successful drug, was patented on March 6, 1899 and was called "Aspirin" (A- from Acetyl, -spirfrom Spiraea ulmaria [meadowsweet, which also contains salacin] and -in as a then typical name-ending for medicines). ${ }^{5,6}$

Nowadays, aspirin is most widely known for its application in strategies to reduce cardiovascular risk, due to its anticoagulant properties first discovered by Lawrence L Craven, a general practitioner from Glendale, California, in the 1940s, who observed increased bleeding in children who chewed aspirin gum after tonsillectomy. He started prescribing an aspirin a day to overweight middle-aged men with sedentary lifestyles and to patients who had recovered from previous heart attacks. After having treated nearly 8000 patients and noting not a single myocardial infarction or stroke among them, Craven published his results, recommending aspirin as "a safe and effective method of preventing coronary thrombosis". ${ }^{7}$ However, it took more than another 30 years and the publication of the first systematic data showing aspirin use to be associated with a reduction in myocardial infarction and stroke, by Elwood in 1974, before the 
US Food and Drug Administration would endorse the recommendation to prescribe aspirin to individuals at high risk for cardiovascular events. ${ }^{1,8,9}$ Since then, many studies have been published on cardiovascular risk reduction strategies based on the use of aspirin in various patient groups. One should distinguish both primary and secondary prevention strategies, and low- and high-risk patient groups, ie, healthy individuals and patients with unfavorable cardiovascular risk profiles, asymptomatic vascular disease, or diabetes. Finally, the benefits of aspirin may be negatively influenced by a feature known as "aspirin resistance" as demonstrated by a lack of response on platelet function testing, and by aspirin's potential for gastrotoxicity.

This article provides an overview for the practicing physician of the literature regarding the effects of aspirin and nonsteroidal anti-inflammatory drugs (NSAIDs) on the gastrointestinal mucosa and the rationale and practice of various strategies to counteract these side effects.

\section{Methods}

We searched Medline for English language articles published up to 2010, using the keywords: acetylsalicylic acid, aspirin, cardiovascular, NSAIDs, adverse effects, gastrointestinal, and proton-pump inhibitors. Abstracts were screened for relevance, and publications relating to aspirin, gastrointestinal side effects, and proton pump inhibitors were obtained. Additional references were identified from the bibliographies of the retrieved reports and from review articles. Further sources of information were retrieved from the Internet.

\section{Aspirin and cardiovascular risk reduction}

The most robust data on the value of aspirin to prevent cardiovascular events are on secondary prevention in patients with occlusive cardiovascular disease (Table 1). In 2002, the Antithrombotic Trialists' Collaboration published a meta-analysis of 287 randomized trials of an antiplatelet regimen versus control or versus another antiplatelet regimen in high-risk patients. ${ }^{10}$ Sixty-five trials were on aspirin alone and 48 on a combination containing aspirin. The prescription of any antiplatelet therapy reduced the combined outcome of any serious vascular event by about one quarter, nonfatal myocardial infarction by one third, nonfatal stroke by one quarter, and vascular mortality by one sixth. Absolute risk reductions mainly varied by patients' absolute risk, being 36 per 1000 treated for two years in patients with previous myocardial infarction or stroke and 22 per 1000 treated for other high-risk patients. The results for aspirin were similar to that of all antiplatelet therapies taken together. High-dose aspirin (500-1500 mg daily) was no more effective than medium-dose (160-325 mg) or low-dose (75-150 mg) aspirin. ${ }^{10}$ In the context of acute ischemic stroke, aspirin treatment is associated with a definite benefit during hospitalization and in posthospital prognosis. A combined analysis of the pooled data of two major trials on this subject, comprising data for 40,000 patients, showed a reduction of 9 per $1000(2 P=0.001)$ in the overall risk for further stroke or death in hospital. ${ }^{11}$

The most recent meta-analysis from the previously mentioned Antithrombotic Trialists' Collaboration analyzed the available individual participant data for both secondary and primary cardiovascular prevention using aspirin. ${ }^{12}$ Results from primary and secondary prevention data were similar for men and women regarding the proportional reductions in the aggregate of all serious vascular events. The study confirmed previous conclusions regarding secondary prevention by showing a statistically and clinically significant reduction in serious vascular events $(6.7 \%$ with aspirin versus $8.2 \%$ with placebo per year), with similar results in both men and women. However, results for primary prevention are disappointing. Six randomized, controlled, primary prevention trials were included, covering 95,000 individuals at low average risk with 660,000 person-years of follow-up. Aspirin allocation yielded a $12 \%$ proportional reduction in serious vascular events $(0.51 \%$ with aspirin versus $0.57 \%$ in controls per year, $P=0.0001)$, mainly due to a reduction in nonfatal myocardial infarction $(0.18 \%$ versus $0.23 \%$ per year, $P<0.0001)$. The incidence of stroke and vascular mortality did not differ significantly. In the view of an increase in major gastrointestinal and other extracranial bleeding $(0.10 \%$ versus $0.07 \%$ per year, $P<0.0001$ ), the net benefit of aspirin in the primary prevention of cardiovascular events remains subject to discussion. ${ }^{12}$

In search of intermediate patient groups that might indeed take advantage of treatment with aspirin to reduce the occurrence of future occlusive vascular disease, studies were done in patients with diabetes mellitus and asymptomatic vascular disease. A meta-analysis on seven prospective, randomized, controlled trials including 11,618 diabetes mellitus patients, with follow-up of 3.7-10.1 years, showed that aspirin therapy was not associated with a significant reduction in major cardiovascular events $(11.1 \%$ with aspirin versus $12.1 \%$ in controls, relative risk [RR], 0.92; 95\% confidence intervals [CI]: $0.83-1.02)$ or deaths $(6.4 \%$ with aspirin versus $7.0 \%$ in controls, RR, 0.95; 95\% CI: 0.71-1.27). ${ }^{13}$ Even though aspirin did not significantly increase the risk of major bleeding 
Table I Aspirin in the primary and secondary prevention of cardiovascular disease

\begin{tabular}{|c|c|c|c|c|}
\hline Study & Population & Methods & Results & Conclusion \\
\hline Chen et al" & $\begin{array}{l}\text { Acute ischemic } \\
\text { stroke }(n=40,000)\end{array}$ & $\begin{array}{l}\text { Meta-analysis of } \\
\text { two RCTs }\end{array}$ & $\begin{array}{l}9 / 1000(8.2 \% \\
\text { aspirin versus } 9.1 \% \\
\text { control, } 2 P=0.00 I) \text { proportional } \\
\text { reduction in recurrent stroke } \\
\text { or inhospital death }\end{array}$ & $\begin{array}{l}\text { Early aspirin is of } \\
\text { benefit in patients with } \\
\text { suspected acute ischemic } \\
\text { stroke }\end{array}$ \\
\hline $\begin{array}{l}\text { Antithrombotic } \\
\text { Trialists' } \\
\text { Collaboration }^{12}\end{array}$ & $\begin{array}{l}\text { Primary }(n=95,000, \\
660,000 \text { py) and } \\
\text { secondary prevention } \\
(n=17,000,43,000 \text { py) } \\
\text { of serious vascular events } \\
\text { (myocardial infarction, } \\
\text { stroke, vascular death) }\end{array}$ & $\begin{array}{l}\text { Meta-analysis of } \\
\text { six primary prevention } \\
\text { and } 16 \text { secondary } \\
\text { prevention trials }\end{array}$ & $\begin{array}{l}\text { Risk reduction primary } \\
\text { prevention I } 2 \% \\
(0.5 \mathrm{I} \% \text { aspirin versus } \\
0.57 \% \text { control, } P=0.000 \mathrm{I}) \\
\text { Major bleeding } 0.10 \% \\
\text { aspirin versus } 0.07 \% \\
\text { control, } P<0.000 \mathrm{I}) \\
\text { Risk reduction } \\
\text { secondary prevention } \\
18 \%(6.7 \% \text { aspirin versus } \\
8.2 \% \text { control, } P<0.000 \mathrm{I})\end{array}$ & $\begin{array}{l}\text { Aspirin is of benefit in } \\
\text { secondary prevention } \\
\text { of serious vascular events; } \\
\text { the net benefit, considering } \\
\text { risk of major bleeding, } \\
\text { in primary prevention } \\
\text { is uncertain }\end{array}$ \\
\hline Zhang et $\mathrm{al}^{13}$ & $\begin{array}{l}\text { Primary prevention of } \\
\text { cardiovascular events } \\
\text { in patients with } \\
\text { diabetes }(n=\mid 1,618)\end{array}$ & $\begin{array}{l}\text { Meta-analysis of } \\
\text { seven RCTs }\end{array}$ & $\begin{array}{l}\text { No reduction in serious } \\
\text { cardiovascular events } \\
(11.1 \% \text { aspirin versus } \\
12.1 \% \text { control, RR } 0.92 \text {; } \\
95 \% \mathrm{Cl} 0.83-1.02) \text { or } \\
\text { death }(6.4 \% \text { aspirin } \\
\text { versus } 7.0 \text { control, } \\
\text { RR } 0.95 ; 95 \% \mathrm{Cl} 0.7|-| .27)\end{array}$ & $\begin{array}{l}\text { Aspirin does not reduce } \\
\text { the risk of occlusive } \\
\text { vascular disease or death } \\
\text { in patients with diabetes } \\
\text { mellitus at otherwise } \\
\text { low risk for occlusive } \\
\text { vascular disease }\end{array}$ \\
\hline Fowkes et $\mathrm{al}^{15}$ & $\begin{array}{l}\text { Primary prevention of } \\
\text { nonfatal coronary event, } \\
\text { stoke or revascularization } \\
\text { in patients with } \\
\text { asymptomatic vascular } \\
\text { disease, ie, patients with } \\
\text { low ankle brachial } \\
\text { index }(\mathrm{n}=28,980)\end{array}$ & Double-blind RCT & $\begin{array}{l}\text { No reduction in vascular } \\
\text { events }(13.7 / 1000 \text { py } \\
\text { aspirin versus I3.3//000 } \\
\text { py placebo, HR I.03; } \\
95 \% \mathrm{Cl} 0.84-1.27)\end{array}$ & $\begin{array}{l}\text { In patients with } \\
\text { subclinical atherosclerotic } \\
\text { vascular disease aspirin } \\
\text { does not reduce the risk } \\
\text { for occlusive vascular events }\end{array}$ \\
\hline Berger et al ${ }^{17}$ & $\begin{array}{l}\text { Primary prevention } \\
\text { in patients with } \\
\text { peripheral artery } \\
\text { disease }(n=5269)\end{array}$ & $\begin{array}{l}\text { Meta-analysis } \\
\text { of } 18 \text { RCTs }\end{array}$ & $\begin{array}{l}\text { No reduction in nonfatal } \\
\text { myocardial infarction, } \\
\text { nonfatal stroke }(8.9 \% \\
\text { aspirin versus II.0 control, } \\
\text { RR } 0.88 ; 95 \% \mathrm{Cl} 0.76-1.04) \text {, } \\
\text { or cardiovascular death } \\
(8.0 \% \text { aspirin versus } \\
8.8 \text { control, RR } 0.98 \text {; } \\
95 \% \mathrm{Cl} 0.83-\mathrm{I.I7})\end{array}$ & $\begin{array}{l}\text { No significant benefit } \\
\text { of aspirin on the occurrence } \\
\text { of serious cardiovascular } \\
\text { events in patients with } \\
\text { peripheral artery disease }\end{array}$ \\
\hline
\end{tabular}

Abbreviations: $\mathrm{Cl}$, confidence interval; RR, relative risk; RCT, randomized controlled trial; py, patient years.

(3.0\% with aspirin versus $1.7 \%$ in controls, RR, 2.46; $95 \%$ CI: 0.70-8.61), based on these data aspirin has no place in the routine management of patients with diabetes mellitus at otherwise low risk for occlusive vascular disease. This recommendation was recently endorsed jointly by the American Diabetes Association, American Heart Association, and American College of Cardiology. ${ }^{13,14}$

There is no meta-analysis available on prescription of aspirin to patients with asymptomatic vascular disease. However, a recent double-blind, randomized, controlled trial showed no benefit of aspirin versus placebo after a mean follow-up of 8.2 years in reducing the primary endpoint of fatal or nonfatal coronary events, strokes, or revascularizations in otherwise healthy individuals with asymptomatic occlusive vascular disease as suspected by a low ankle brachial index on screening (13.7 per 1000 person-years with aspirin versus 13.3 per 1000 person-years with placebo, hazard ratio [HR], 1.03; 95\% CI: $0.84-1.27) .{ }^{15}$ Even though the study was underpowered to detect a smaller than $25 \%$ difference in the primary study outcome, and one might raise questions on the ankle brachial index to diagnose subclinical vascular disease, these data do not indicate a clinically relevant advantage of long-term aspirin use in these individuals. ${ }^{16}$ Furthermore, the findings 
in this trial are supported by findings in a meta-analysis on aspirin for the prevention of cardiovascular events in patients with overt peripheral artery disease, that could only demonstrate a reduction in nonfatal stroke, but not in all primary cardiovascular endpoints. This meta-analysis on 18 randomized controlled trials involving 5269 patients, found similar rates in aspirin-treated patients versus controls for cardiovascular events $(8.9 \%$ with aspirin versus $11.0 \%$ in controls, RR, $0.88 ; 95 \%$ CI: $0.76-1.04)$ or any death $(8.0 \%$ with aspirin versus $8.8 \%$ in controls, RR, 0.98 ; 95\% CI: $0.83-1.17){ }^{16,17}$

Besides underlying disease and absolute risk, whether the individual patient benefits from long-term aspirin use might also depend on the phenomenon of "aspirin resistance", ie, the observation that some patients require a higher dose of aspirin than is normally recommended to achieve the expected antiplatelet effect. The cause of this insufficient response has not yet been fully elucidated, and may be a composite of low dosage, incompliance, variations in absorbing capacities, and/or underlying genetic predispositions. ${ }^{18}$ The disappointing results of aspirin therapy in diabetes patients may in part be due to biochemical interactions leading to diminished effects of aspirin on platelet function in these patients. ${ }^{19}$ Regardless of the mechanisms involved, a meta-analysis on 20, mainly cohort, studies totaling 2930 patients with cardiovascular disease using aspirin in a dose of 75-325 mg daily, showed $810(28 \%)$ of the patients to be aspirin-resistant. Aspirinresistant patients were at a greater risk of death, acute coronary syndrome, failure of vascular intervention or a new cerebrovascular event; 39\% of the aspirin-resistant patients experienced a cardiovascular event compared with
$16 \%$ of the aspirin-sensitive patients (odds ratio [OR], 3.85; 95\% CI: $3.08-4.80) .{ }^{18}$

\section{Aspirin and upper gastrointestinal side effects}

It is now estimated that 50 million Americans have started on aspirin for cardiovascular prevention. ${ }^{20}$ Aspirin use is associated with a wide variety of upper gastrointestinal side effects. These side effects range from dyspepsia to acute mucosal damage, erosions, ulcers, and ulcer complications, such as ulcer bleeding and death. There is increasing evidence that a large proportion of hospitalizations for gastrointestinal bleeding is now attributable to low-dose aspirin use. In a recent nationwide observational study from Spain, low-dose aspirin was found to be responsible for $12 \%$ of all severe gastrointestinal events and associated deaths. ${ }^{21}$ Mortality attributable to the use of NSAIDs or aspirin is estimated to be 20-25 cases per million people. One third of these are attributable to low-dose aspirin. ${ }^{21}$ The earliest report on aspirin-induced gastric damages, however, dates back nearly 75 years, when Douthwaite and Lintott used rigid endoscopy to report aspirin-induced gastric damage in a series of patients in $1938 .^{22}$

Dyspepsia is common in aspirin and in nonaspirin NSAID users, being reported by $15 \%-40 \%$ of patients and causing $10 \%$ to discontinue their NSAID treatment. ${ }^{23}$ However, there is a poor correlation between dyspeptic symptoms and mucosal damage, because approximately half of NSAIDusing patients with dyspeptic symptoms have normal mucosa upon endoscopy. ${ }^{24}$ In a prospective study of 187 patients taking low-dose aspirin as cardiovascular prophylaxis, $20 \%$ of patients reported dyspeptic symptoms, again with a

Table 2 Gastrointestinal bleeding risk associated with use of low-dose aspirin

\begin{tabular}{|c|c|c|c|c|}
\hline Study & Population & Methods & Results & Conclusion \\
\hline Derry and Loke ${ }^{20}$ & $\begin{array}{l}\text { Low-dose aspirin use } \\
\text { as antiplatelet agent } \\
(\mathrm{n}=66,000)\end{array}$ & $\begin{array}{l}\text { Meta-analysis } \\
\text { of } 24 \text { RCTs }\end{array}$ & $\begin{array}{l}\text { I.05\% absolute risk increase } \\
\text { for gastrointestinal bleeding } \\
\text { ( } 2.47 \% \text { aspirin versus I. } 42 \% \\
\text { placebo, OR I.68; } 95 \% \\
\text { CI I.5I-I.88) }\end{array}$ & $\begin{array}{l}\text { Long-term therapy with aspirin } \\
\text { is associated with a significant } \\
\text { increase in the incidence } \\
\text { of gastrointestinal hemorrhage }\end{array}$ \\
\hline McQuaid and Laine ${ }^{33}$ & $\begin{array}{l}\text { Low-dose aspirin or } \\
\text { clopidogrel use for } \\
\text { cardiovascular prophylaxis } \\
\text { (n = 57,000 on aspirin) }\end{array}$ & $\begin{array}{l}\text { Meta-analysis } \\
\text { of I4 RCTs }\end{array}$ & $\begin{array}{l}\text { Absolute increase in major } \\
\text { gastrointestinal bleeding } \\
\text { episodes (I.7// } 000 \text { aspirin } \\
\text { versus } 0.97 / 1000 \text { placebo, } \\
\text { RR } 2.07 ; 95 \% \mathrm{Cl} \text { I.6I-2.66) }\end{array}$ & $\begin{array}{l}\text { Low-dose aspirin increases the } \\
\text { risk of major bleeding by } \\
\text { approximately } 70 \% \text {; the absolute } \\
\text { increase in bleeding risk is small }\end{array}$ \\
\hline Sorensen et $\mathrm{al}^{34}$ & $\begin{array}{l}\text { Low-dose aspirin in general } \\
\text { population }(n=27,694)\end{array}$ & Cohort study & $\begin{array}{l}\text { Increase in rate of } \\
\text { hospitalization for upper } \\
\text { gastrointestinal bleeding } \\
\text { (I.3/1000 aspirin versus } \\
0.6 / 1000 \text { general population, } \\
\text { RR } 2.6 ; 95 \% \mathrm{Cl} 2.2-2.9)\end{array}$ & $\begin{array}{l}\text { Use of low-dose aspirin is } \\
\text { associated with an increased risk } \\
\text { of upper gastrointestinal bleeding }\end{array}$ \\
\hline
\end{tabular}

Abbreviations: $\mathrm{Cl}$, confidence interval; $\mathrm{RR}$, relative risk; $\mathrm{RCTs}$, randomized controlled trials; OR, odds ratio. 
poor correlation between dyspeptic symptoms and mucosal damage. ${ }^{25}$ The mechanisms by which aspirin and nonaspirin NSAIDs induce dyspepsia is not clear.

Although some topical gastroduodenal injury may occur through local irritant effects of aspirin on the gastric epithelium, postabsorptive systemic inhibition of gastrointestinal COX-1 and subsequent inhibition of prostaglandin synthesis probably plays a dominant role in the pathogenesis of aspirin-induced mucosal damage. Use of enteric-coated or buffered aspirin, designed to resist disintegration in the stomach and dissolving in the more alkaline environment of the duodenum, does not appear to decrease the risk of major upper gastrointestinal bleeding and neither does parenteral or transdermal COX inhibition. ${ }^{26}$ Furthermore, rates of peptic ulcer development in patients taking low-dose aspirin are similar to those in patients taking effervescent calcium carbasalate, a more easily dissolvable form of aspirin, that reduces the possibility of increased localized aspirin concentrations. The damaging effects of aspirin and nonaspirin NSAIDs on the gastroduodenal mucosa are therefore thought to be mainly systemic, and enteric-coated preparations may not be assumed to be fully gastroprotective. By inhibition of gastrointestinal COX-1, aspirin may reduce mucosal blood flow causing local ischemic injury. This ischemia-reperfusion injury may occur very early after NSAID administration.

Aspirin may further impair specific prostaglandindependent defenses which protect the gastric mucosa, such as the secretion of the thick bicarbonate-containing mucous layer lining the interior of the stomach, which buffers luminal gastric acid and thus protects the stomach wall. When these defenses have been weakened, a second wave of injury caused by luminal gastric acid may facilitate deeper ulceration and even perforation of the stomach wall. ${ }^{23}$ Due to the concurrent inhibition of blood platelet aggregation, aspirin-induced gastrointestinal ulcers may have an increased tendency to bleed. Inhibition of prostaglandin synthesis reduces epithelial cell turnover and repair, and mucosal immunocyte function. ${ }^{27}$

Neutrophils have been shown to play a role in NSAID gastropathy, and intracellular adhesion molecule 1 and tumor necrosis factor-alpha may mediate neutrophil adherence within the gastric microcirculation. ${ }^{28}$ NSAIDs can also inhibit the healing of pre-existing lesions by interfering with the process of restitution, leading to the formation of hemorrhagic mucosal erosions. However, it has also been shown that the stomach may adapt to repeated exposure to aspirin and that long-term aspirin use increases the resistance of the stomach to damage by NSAIDs and other irritants..$^{28,29}$
Mucosal damage may occur within minutes after exposure to aspirin, and may either heal or develop into ulcers. ${ }^{30}$ Superficial damage or erosions occur in approximately 50\% of asymptomatic patients on long-term treatment with low-dose aspirin. ${ }^{25}$ In the previously mentioned study of 187 patients using lowdose aspirin for cardiovascular protection, the point prevalence of endoscopic ulcers was $11 \%$ (95\% CI: $6.3 \%-15.1 \%)$ and the three-month incidence was $7 \%$ (95\% CI: $2.4 \%-11.8 \%) .{ }^{25}$ However, the only placebo-controlled study of the occurrence of low-dose aspirin-associated endoscopic ulcers did not find significantly different incidence rates between enteric-coated aspirin $81 \mathrm{mg} /$ day $(7.3 \%)$ and placebo (5.8\%) at three months. ${ }^{31}$ However, the clinical significance of these findings is unclear, because the incidence of endoscopic ulcers is far greater than the incidence of more clinically relevant upper gastrointestinal complications, such as ulcer bleeding or perforation. Although endoscopic ulcers are often taken as the primary endpoint in clinical trials, the real target of prevention is gastrointestinal complications, which unlike endoscopic ulcers are associated with significant morbidity and mortality rates. The numbers needed to treat to prevent a gastrointestinal complication is usually much higher than the numbers needed to treat to prevent an endoscopic ulcer. The risk of aspirin-associated gastrointestinal complications can be assessed in the safety data from numerous placebo-controlled trials primarily designed to evaluate the efficacy of low-dose aspirin in preventing cardiovascular events. ${ }^{10,20,32,33}$ One meta-analysis of 24 randomized controlled trials with almost 66,000 participants demonstrated a one percent absolute risk increase for aspirin compared with placebo. Gastrointestinal bleeding occurred in $2.47 \%$ of patients taking aspirin compared with $1.42 \%$ of patients taking placebo, at an average of 28 months (OR, 1.68 [95\% CI: 1.5-1.88] and number needed to harm 106 [95\% CI: 82-140]). ${ }^{20}$ In a meta-analysis of 14 randomized placebo-controlled trials with over 57,000 patients on low-dose aspirin (75-325 mg/day), the RR of major gastrointestinal bleeding that was fatal or required hospitalization or transfusion was 2.07 with aspirin versus placebo $(95 \%$ CI: 1.61-2.66). The pooled incidence of major gastrointestinal bleeding was 1.2 per 1000 patients per year (absolute annual increase in risk $0.12 \%$; 95\% CI: $0.07 \%-0.19 \%$ ). Based on this value, 833 patients (95\% CI: 526-1429 patients) would need to be treated with low-dose aspirin instead of placebo for one year to cause one major gastrointestinal bleeding episode (the number needed to harm was 833). ${ }^{33}$

The results from the randomized controlled trials are generally consistent with the results from observational studies, where the OR of gastrointestinal bleeding has been in the range $1.3-3.2 .{ }^{28}$ In a five-year observational study from 
Denmark, hospitalization for gastrointestinal bleeding was assessed in a cohort of 27,694 patients using low-dose aspirin, and compared with that in the general population. ${ }^{34}$ Rate of hospitalization for upper gastrointestinal bleeding in patients without aspirin, NSAIDs, anticoagulants, corticosteroids, or conditions predisposing to gastrointestinal bleeding was 0.6 per 1000 patients per year. The absolute annual incidence of gastrointestinal bleeding in patients with aspirin was 1.3 per 1000 patients per year (RR, 2.6; 95\% CI: 2.2-2.9). ${ }^{34}$ The higher rates of gastrointestinal bleeding seen in observational studies than in randomized controlled trials may reflect the fact that patients who are at increased risk for gastrointestinal bleeding would generally have been excluded from participating in randomized controlled trials (Table 2).

\section{Risk factors for NSAID-related gastrointestinal disease}

Multiple studies have identified additional risk factors for the development of gastrointestinal ulcers during NSAID use. Risk factors include advanced age, a prior history of ulcers, high-dosage or multiple NSAIDs, concurrent use of corticosteroids, anticoagulants, aspirin, platelet inhibitors, or serotonin reuptake inhibitors, infection with Helicobacter pylori and the presence of comorbid conditions, such as diabetes mellitus, heart failure, or rheumatoid arthritis. ${ }^{35}$ There have been few studies that have specifically determined risk factors associated with low-dose aspirin use, but many of the risk factors identified for nonaspirin NSAIDs have also been suggested as risk factors for low-dose aspirin-associated ulcers. In the US Preventative Services Task Force report on the use of aspirin for the primary prevention of cardiovascular disease, the risk was estimated to be two to three times higher in patients with a history of gastrointestinal ulcers and twice as high for men as for women. ${ }^{36}$ In a population-based case-control study of 1443 Danish patients with major upper gastrointestinal bleeding and 57,720 controls, the adjusted OR for gastrointestinal bleeding was 1.8 (95\% CI: 1.5-2.1) for aspirin, 1.1 (95\% CI: 0.6-2.1) for clopidogrel, 1.9 (95\% CI: 1.3-2.8) for dipyridamole, 1.8 (95\% CI: 1.3-2.4) for vitamin $\mathrm{K}$ antagonists, 7.4 (95\% CI: 3.5-15) for aspirin and clopidogrel, 5.3 (95\% CI: 2.9-9.5) for aspirin and vitamin K antagonists, and 2.3 (95\% CI: 1.7-3.5) for aspirin and dipyridamole. ${ }^{23,37}$ These results demonstrate that combined antithrombotic therapy with low-dose aspirin is associated with a higher risk of gastrointestinal bleeding. Other risk factors that have been implicated in the development of gastrointestinal ulcers during chronic aspirin use include advanced age ( $\geq 60$ years), presence of severe disease, concurrent use of COX-2 selective or nonselective NSAIDs, concurrent use of corticosteroids, symptoms of dyspepsia or GERD, and infection with H. pylori. ${ }^{38,39}$

Some observational studies also suggest that the risk of gastrointestinal bleeding is increased at higher aspirin doses. One large case control study in 2777 consecutive patients with endoscopy-proven major upper gastrointestinal bleeding and 5532 controls showed clear dose dependency, with an adjusted RR, of 2.7 (95\% CI: 2.0-3.6) for aspirin $100 \mathrm{mg}$ daily, 6.1 (95\% CI: 4.3-8.7) for aspirin $300 \mathrm{mg}$ daily, and 10.4 (6.1-17.8) for aspirin $1000 \mathrm{mg}$ daily. ${ }^{10,40}$ However, in direct randomized comparisons, no significant associations were found between different low aspirin doses (75-325 mg daily) and risk of bleeding. ${ }^{20}$ Likewise, in indirect comparison in a meta-analysis conducted by the Antithrombotic Trialists' Collaboration, there was no significant difference in risk at doses of 75-325 mg daily. ${ }^{10}$ The incidence of severe or life-threatening bleeding in relation to the aspirin dose (less than $100 \mathrm{mg}, 100 \mathrm{mg}$, or more than $100 \mathrm{mg}$ daily) was also evaluated in a nonrandomized, post hoc subgroup analysis from the CHARISMA (Clopidogrel for High Atherothrombotic Risk and Ischemic Stabilization, Management, and Avoidance) trial. ${ }^{41}$ In this trial, nearly 16,000 patients with either established cardiovascular disease or at high risk were given aspirin in a daily dose left to the discretion of the investigators and were randomly assigned to concomitant clopidogrel $75 \mathrm{mg}$ daily or placebo. At a median of 28 months, there were no significant differences in the incidence of severe or life-threatening bleeding between the different aspirin dose groups and no effect modification was found for clopidogrel. ${ }^{41}$ In the previously mentioned systematic review of 22 randomized trials of low-dose aspirin (75-325 mg/day) or clopidogrel, no difference was seen between 75-162.5 mg daily and 162.5-325 mg daily. ${ }^{33}$ Therefore, the case for a dose-response relationship between aspirin dose and risk of gastrointestinal bleeding is not entirely clear, at least in the low-dose aspirin range up to $325 \mathrm{mg}$ daily. Daily doses of $75 \mathrm{mg}$ aspirin for a few consecutive days provides virtually complete inhibition of COX-1 in blood platelets, and doses above 75-150 mg do not confer additional benefits for the prevention of cardiovascular events. ${ }^{10}$ Therefore, more than $150 \mathrm{mg}$ aspirin should not be prescribed for cardiovascular risk reduction.

\section{Risk reduction strategies}

Several strategies have been proposed to minimize the risk of upper gastrointestinal bleeding in low-dose aspirin users. These include using the lowest effective aspirin dose ( $<100 \mathrm{mg}$ daily), concomitant use of gastroprotective agents, 
such as proton pump inhibitors, $\mathrm{H}_{2}$-receptor antagonists, or prostaglandin replacement with the prostaglandin $\mathrm{E}_{1}$ analog, misoprostol, use of alternative platelet inhibitors, such as clopidogrel and eradication of $H$. pylori.

\section{Helicobacter pylori eradication}

$H$. pylori and NSAIDs are the most important independent risk factors for peptic ulcers and ulcer bleeding, and peptic ulcers are rare in $H$. pylori-negative non-NSAID users. ${ }^{42}$ There also appears to be synergism for the development of peptic ulcers and ulcer bleeding between $H$. pylori infection and NSAID use. The baseline risk for a new $H$. pylori ulcer in patients with latent $H$. pylori infection is approximately $1 \%$ per year ( 1 per 100 patient years), independent of NSAID use. The baseline risk for a new $H$. pylori ulcer complication in patients with latent $H$. pylori infection is very small, ie, $<1$ per 1000 patient years. However, in patients with a history of $H$. pylori-related ulcers, the baseline risk of endoscopic recurrence is $50 \%-100 \%$ within any one year, even without NSAID exposure. In patients with a history of H. pylori ulcer complications, the risk of a new ulcer complication is $1 \%-3 \%$ per month, again even without NSAID exposure. ${ }^{43}$ A meta-analysis of observational studies showed that $H$. pylori infection and NSAID use increased the risk of ulcer bleeding 1.79-fold and 4.85-fold, respectively. However, the risk of ulcer bleeding increased to 6.13 when both factors were present. ${ }^{44} \mathrm{H}$. pylori eradication prevents or greatly reduces the risk of recurrence of $H$. pylori ulcers. However, in NSAID users, H. pylori eradication would be expected to be less effective. A meta-analysis of five randomized trials with 939 patients on the efficacy of $H$. pylori eradication in NSAID users showed that $7.4 \%$ patients developed a peptic ulcer in the eradicated group versus $13.3 \%$ in the control group (OR 0.43; 95\% CI: 0.20-0.93). Subanalyses showed a significant risk reduction for NSAID-naïve patients (OR $0.26,95 \%$ CI: $0.14-0.49$ ) but not in previous NSAID users (OR 0.95; 95\% CI: $0.53-1.72$ ). ${ }^{45}$ This is consistent with the view that $H$. pylori infection enhances NSAID gastrotoxicity or that NSAIDs exacerbate $H$. pylori ulcers or ulcerogenesis. The failure of $H$. pylori eradication in chronic NSAID users may reflect selection bias of $H$. pylori-positive NSAID survivors, because patients who develop ulcers early after starting on NSAIDs would likely discontinue their NSAID treatment. ${ }^{28} \mathrm{H}$. pylori infection is also associated with increased risk of gastrointestinal ulcers in low-dose aspirin users. ${ }^{46}$ There have been no studies evaluating $H$. pylori eradication for the primary prevention of low-dose aspirin-associated ulcer bleeding. However, in low-dose aspirin users with ulcers or ulcer bleeding, eradication of $H$. pylori reduces the risk of recurrence. ${ }^{42,47}$ In one randomized controlled trial, $400 \mathrm{H}$. pylori-positive patients with upper gastrointestinal bleeding (250 with aspirin and 150 with other NSAIDs) were randomly assigned to omeprazole $20 \mathrm{mg}$ daily for six months or one week of eradication therapy, while continuing on either aspirin $80 \mathrm{mg}$ daily or naproxen $500 \mathrm{mg}$ twice daily. Among those taking aspirin, the probability of recurrent bleeding during the six-month period was similar for patients who received eradication therapy and for patients who received omeprazole ( $1.9 \%$ and $0.9 \%$ respectively, absolute difference $1.0 \%, 95 \% \mathrm{CI}$ : for the difference, $-1.9 \%-3.9 \%) .{ }^{47}$ In highrisk patients with continued aspirin use over longer periods of time, $H$. pylori eradication alone may not be sufficient to prevent recurrent bleeding. In a randomized, controlled trial with $123 \mathrm{H}$. pylori-positive patients with low-dose aspirinassociated ulcer complications, the patients were randomly assigned to lansoprazole $30 \mathrm{mg}$ daily or placebo, in addition to aspirin $100 \mathrm{mg}$ daily, for 12 months after ulcer healing and eradication of $H$. pylori infection. Recurrence of ulcer complications occurred in $14.8 \%$ in the placebo group and in $1.6 \%$ in the lansoprazole group (adjusted HR, 9.6, 95\% CI: $1.2-76.1 ; P=0.008) .{ }^{48}$

\section{Gastroprotective agents}

National and international guidelines for the prevention of NSAID-associated upper gastrointestinal complications consistently recommend the use of proton pump inhibitors. In fact, there is a lack of prospective clinical trial data supporting this, as was demonstrated in a meta-analysis of randomized clinical trials on the prevention of NSAID-induced gastrointestinal ulcers. ${ }^{49}$ Misoprostol was the only prophylactic agent documented to reduce NSAID ulcer complications such as perforation, bleeding, or obstruction, but caused significant gastrointestinal side effects, such as abdominal pain and diarrhea, which limits its use in daily clinical practice. Both double-dose $\mathrm{H}_{2}$-receptor antagonists and proton pump inhibitors were effective at reducing the risk of endoscopic duodenal ulcers (RR, 0.44; 95\% CI: $0.26-0.74)$ and gastric ulcers (RR, 0.40; 95\% CI: 0.32-0.51) and were better tolerated than misoprostol (Table 3 ). ${ }^{49}$

There are also limited data available on the efficacy of gastroprotective agents for the prevention of low-dose aspirininduced gastrointestinal complications. In a double-blind, placebo-controlled endoscopy study, 32 healthy volunteers took aspirin $300 \mathrm{mg}$ daily for 28 days. Most subjects developed erosions of the gastric mucosa, which was significantly reduced by misoprostol $100 \mu \mathrm{g}$ daily (OR, 0.18; 95\% CI: 0.07-0.48) without causing identifiable adverse effects. ${ }^{50}$ 
Table 3 Efficacy of gastroprotective agents for the prevention of low-dose aspirin-associated gastrointestinal complications

\begin{tabular}{|c|c|c|c|c|c|}
\hline & Study & Population & Methods & Results & Conclusion \\
\hline Misoprostol & $\begin{array}{l}\text { Donnelly } \\
\text { et } \mathrm{al}^{50}\end{array}$ & $\begin{array}{l}\text { Healthy volunteers } \\
(n=32)\end{array}$ & $\begin{array}{l}\text { Double-blind, } \\
\text { placebo-controlled } \\
\text { endoscopy study }\end{array}$ & $\begin{array}{l}\text { Reduced incidence } \\
\text { of } \geq I \text { gastric erosion } \\
\text { when using } \\
\text { misoprostol } \\
\text { (I } 17 \% \text { aspirin- } \\
\text { misoprostol versus } \\
52 \% \text { aspirin-placebo, } \\
\text { OR } 0.18 ; 95 \% \\
\text { CI } 0.07-0.48 \text { ) }\end{array}$ & $\begin{array}{l}\text { Misoprostol can } \\
\text { prevent low-dose } \\
\text { aspirin-induced } \\
\text { gastric mucosal } \\
\text { injury }\end{array}$ \\
\hline \multirow[t]{3}{*}{$\begin{array}{l}\mathrm{H}_{2} \text {-receptor } \\
\text { antagonists }\end{array}$} & $\begin{array}{l}\text { Taha } \\
\text { et } \mathrm{al}^{5 !}\end{array}$ & $\begin{array}{l}\text { Patients with cardiovascular } \\
\text { or cerebrovascular } \\
\text { disease or diabetes } \\
\text { using low-dose } \\
\text { aspirin }(n=404)\end{array}$ & $\begin{array}{l}\text { Randomized, double-blind, } \\
\text { placebo-controlled trial }\end{array}$ & $\begin{array}{l}\text { Reduced incidence of } \\
\text { endoscopic gastric ulcers } \\
\text { ( } 3.4 \% \text { famotidine versus I } 5 \% \\
\text { placebo, OR } 0.20 \text {; } 95 \% \\
\mathrm{Cl} 0.09-0.47) \text {, duodenal } \\
\text { ulcers ( } 0.5 \% \text { famotidine } \\
\text { versus } 8.5 \% \text { placebo, OR } 0.05 \text {; } \\
95 \% \mathrm{Cl} 0.0 \text { I-0.40), and erosive } \\
\text { esophagitis ( } 4.4 \% \text { famotidine } \\
\text { versus } 19 \% \text { placebo, OR } 0.20 \text {; } \\
95 \% \mathrm{Cl} 0.09-0.42 \text { ) } \\
\text { after } 12 \text { weeks }\end{array}$ & $\begin{array}{l}\text { Famotidine is effective } \\
\text { in the prevention of } \\
\text { gastric and duodenal } \\
\text { ulcers, and erosive } \\
\text { esophagitis in patients } \\
\text { taking low-dose aspirin }\end{array}$ \\
\hline & $\begin{array}{l}\text { Lanas } \\
\text { et } \mathrm{al}^{52}\end{array}$ & $\begin{array}{l}\text { Patients with endoscopy } \\
\text { confirmed upper } \\
\text { gastrointestinal } \\
\text { bleeding ( } n=2777, \\
5532 \text { controls) }\end{array}$ & Case-control study & $\begin{array}{l}\text { Adjusted relative risk } \\
\text { of } 0.40(95 \% \mathrm{Cl} 0.19-0.73) \\
\text { for upper gastrointestinal } \\
\text { bleeding in low-dose aspirin } \\
\text { users with concomitant } \\
\text { use of } \mathrm{H}_{2} \text {-receptor antagonists }\end{array}$ & $\begin{array}{l}\mathrm{H}_{2} \text {-receptor antagonist } \\
\text { use is associated } \\
\text { with reduced upper } \\
\text { gastrointestinal bleeding } \\
\text { in patients taking aspirin }\end{array}$ \\
\hline & $\begin{array}{l}\text { Lanas } \\
\text { et } \mathrm{al}^{53}\end{array}$ & $\begin{array}{l}\text { Patients taking low-dose } \\
\text { aspirin for vascular } \\
\text { prevention with endoscopy } \\
\text { confirmed upper } \\
\text { gastrointestinal } \\
\text { bleeding ( } n=323 \\
\text { matched controls) }\end{array}$ & Case-control study & $\begin{array}{l}\text { Adjusted relative } \\
\text { risk of } 0.50(95 \% \\
\mathrm{Cl} 0.20-1.2) \text { for } \\
\text { upper gastrointestinal } \\
\text { bleeding in low-dose } \\
\text { aspirin users with } \\
\text { concomitant use } \\
\text { of } \mathrm{H}_{2} \text {-receptor } \\
\text { antagonists }\end{array}$ & $\begin{array}{l}\mathrm{H}_{2} \text {-receptor antagonist } \\
\text { use is associated with a } \\
\text { trend to reduced upper } \\
\text { gastrointestinal bleeding } \\
\text { in patients taking aspirin }\end{array}$ \\
\hline \multirow[t]{3}{*}{$\begin{array}{l}\text { Proton } \\
\text { pump } \\
\text { inhibitors }\end{array}$} & $\begin{array}{l}\text { Yeomans } \\
\text { et } \mathrm{al}^{56}\end{array}$ & $\begin{array}{l}\text { Elderly users of } \\
\text { low-dose aspirin } \\
(n=995)\end{array}$ & $\begin{array}{l}\text { Randomized } \\
\text { placebo-controlled } \\
\text { trial }\end{array}$ & $\begin{array}{l}\text { Reduced incidence } \\
\text { of endoscopic } \\
\text { gastroduodenal } \\
\text { ulcers after } 26 \text { weeks' } \\
\text { use of esomeprazole } \\
\text { ( } 1.6 \% \text { esomeprazole } \\
\text { versus } 5.4 \% \text { placebo, } \\
P=0.0007)\end{array}$ & $\begin{array}{l}\text { Esomeprazole reduces } \\
\text { the risk of developing } \\
\text { gastroduodenal ulcers } \\
\text { in elderly patients } \\
\text { taking low-dose aspirin }\end{array}$ \\
\hline & $\begin{array}{l}\text { Lanas } \\
\text { et } \mathrm{al}^{52}\end{array}$ & $\begin{array}{l}\text { Patients with } \\
\text { endoscopy } \\
\text { confirmed upper } \\
\text { gastrointestinal } \\
\text { bleeding ( } \mathrm{n}=2777, \\
5532 \text { controls) }\end{array}$ & Case-control study & $\begin{array}{l}\text { Adjusted risk } \\
\text { reduction of } 0.32 \\
(95 \% \mathrm{Cl} 0.22-0.5 \mathrm{I}) \\
\text { for upper gastrointestinal } \\
\text { bleeding with } \\
\text { concomitant use of } \\
\text { proton pump inhibitors }\end{array}$ & $\begin{array}{l}\text { Proton pump inhibitor } \\
\text { use is associated } \\
\text { with reduced upper } \\
\text { gastrointestinal bleeding } \\
\text { in patients taking aspirin }\end{array}$ \\
\hline & Lanas et $\mathrm{al}^{53}$ & $\begin{array}{l}\text { Patients taking low-dose } \\
\text { aspirin for vascular } \\
\text { prevention with endoscopy } \\
\text { confirmed upper } \\
\text { gastrointestinal bleeding } \\
\text { ( } n=323 \text {, matched controls) }\end{array}$ & Case-control study & $\begin{array}{l}\text { Adjusted relative } \\
\text { risk of } 0.20 \\
(95 \% \mathrm{Cl} 0.10-0.90) \\
\text { for upper gastrointestinal } \\
\text { bleeding in low-dose } \\
\text { aspirin users with } \\
\text { concomitant use of } \\
\mathrm{H}_{2} \text {-receptor antagonists }\end{array}$ & $\begin{array}{l}\text { Proton pump inhibitor } \\
\text { use is associated } \\
\text { with reduced upper } \\
\text { gastrointestinal bleeding } \\
\text { in patients taking aspirin }\end{array}$ \\
\hline
\end{tabular}


Table 3 (Continued)

\begin{tabular}{|c|c|c|c|c|}
\hline Study & Population & Methods & Results & Conclusion \\
\hline $\mathrm{Ng}$ et $\mathrm{al}^{57}$ & $\begin{array}{l}\text { Patients with aspirin-related } \\
\text { peptic ulcers/erosions } \\
(n=160)\end{array}$ & $\begin{array}{l}\text { Randomized placebo- } \\
\text { controlled trial }\end{array}$ & $\begin{array}{l}\text { Reduced recurrence } \\
\text { of ulcers or erosions } \\
\text { in patients taking proton } \\
\text { pump inhibition } \\
\text { compared with high dose } \\
\mathrm{H}_{2} \text {-receptor antagonist } \\
\text { after } 48 \text { weeks } \\
(0 \% \text { pantoprazole } \\
\text { versus } 20 \% \text { famotidine } \\
(P<0.000 \mathrm{I})\end{array}$ & $\begin{array}{l}\text { In patients with } \\
\text { aspirin-related } \\
\text { peptic ulcers/erosions } \\
\text { famotidine is inferior } \\
\text { to pantoprazole in } \\
\text { preventing recurrence }\end{array}$ \\
\hline
\end{tabular}

Abbreviations: $\mathrm{OR}$, odds ratio; $\mathrm{Cl}$, confidence interval.

$\mathrm{H}_{2}$-receptor antagonists including ranitidine, cimetidine, and famotidine, reduce the production of gastric acid through inhibition of the histamine $\mathrm{H}_{2}$-receptor. The efficacy of famotidine in the primary prevention of gastroduodenal ulcers and erosive esophagitis in patients receiving low-dose aspirin was investigated in the FAMOUS (Famotidine for the Prevention of Peptic Ulcers in Users of Low-dose Aspirin) trial, a randomized, double-blind, placebo-controlled trial from the UK. ${ }^{51}$ Patients taking aspirin 75-325 mg per day who did not have ulcers or erosive esophagitis on baseline endoscopy were randomly assigned to receive famotidine $20 \mathrm{mg}$ twice daily or placebo. Endoscopy at 12 weeks revealed gastric ulcers in seven of 204 (3.4\%) patients on famotidine compared with 30 of $200(15 \%)$ patients with placebo (OR, 0.20; 95\% CI: 0.09-0.47), duodenal ulcers in one $(0.5 \%)$ patient with famotidine compared with 17 (8.5\%) with placebo (OR, 0.05 ; 95\% CI: $0.01-0.40)$ and erosive esophagitis in nine (4.4\%) patients with famotidine compared with 38 (19\%) patients with placebo (OR, 0.20; 95\% CI: $0.09-0.42$ ). Four patients in the placebo group were admitted to hospital with upper gastrointestinal bleeding. Therefore, in patients taking low-dose aspirin for vascular protection, high-dose $\mathrm{H}_{2}$-receptor antagonist famotidine was found to be effective in the primary prevention of endoscopic ulcers and erosive oesophagitis. ${ }^{51}$ These data confirm results from previous observational studies. A large Spanish casecontrol study in 2777 patients with endoscopically confirmed upper gastrointestinal bleeding and 5532 matched controls reported an adjusted RR, of 0.40 (95\% CI: 0.19-0.73) for upper gastrointestinal bleeding in low-dose aspirin users with concomitant use of $\mathrm{H}_{2}$-receptor antagonists. ${ }^{52}$ Another case-control study from Spain in 323 patients with lowdose aspirin (up to $300 \mathrm{mg}$ daily for vascular protection) with endoscopically confirmed acute upper gastrointestinal bleeding and matched controls, also demonstrated a 50\% risk reduction of acute upper gastrointestinal bleeding with concomitant $\mathrm{H}_{2}$-receptor antagonists (adjusted OR, 0.5; 95\%
CI: $0.2-1.2) .{ }^{53}$ There have been no randomized, placebocontrolled trials demonstrating the efficacy of $\mathrm{H}_{2}$-receptor antagonists in the primary or secondary prevention of upper gastrointestinal ulcer complications.

Proton-pump inhibitors, including omeprazole, esomeprazole, rabeprazole, pantoprazole, and lansoprazole, reduce the production of gastric acid by inhibiting the parietal cell pump. In healthy volunteers, omeprazole and lansoprazole significantly reduced the risk of endoscopic gastroduodenal lesions induced by aspirin $300 \mathrm{mg}$ daily. ${ }^{54,55}$ The efficacy of esomeprazole for the primary prevention of gastroduodenal ulcers and erosive esophagitis and the treatment of dyspeptic symptoms in patients receiving continuous low-dose aspirin was investigated in a large randomized, placebo-controlled trial from Australia. ${ }^{57}$ Elderly patients aged 60 years and over, without gastroduodenal ulcers at baseline endoscopy who were receiving 75-325 mg aspirin daily were randomized to receive esomeprazole $20 \mathrm{mg}$ daily or placebo. Endoscopy at 26 weeks revealed gastroduodenal ulcers in eight of 493 (1.6\%) patients with esomeprazole compared with 27 of 498 (5.4\%) patients in the placebo group (life-table estimates $1.8 \%$ versus $6.2 \%, P=0.0007$ ). The cumulative proportion of patients with erosive esophagitis at 26 weeks was significantly lower for esomeprazole than placebo ( $4.4 \%$ and $18.3 \%$, respectively, $P<0.0001)$. Esomeprazole was also more likely to resolve symptoms of heartburn, acid regurgitation, and epigastric pain $(P<0.05)$. Therefore, esomeprazole was found to be effective in the primary prevention of endoscopic ulcers and erosive esophagitis and in the treatment of dyspeptic symptoms in patients taking continuous low-dose aspirin for vascular protection..$^{57}$ These data again confirm results from previous observational studies. In the two case-control studies from Spain that are mentioned above, concomitant use of proton pump inhibitors was associated with a significant reduction in the RR of upper gastrointestinal bleeding in low-dose aspirin users. ${ }^{52,53}$ Furthermore, and perhaps more importantly, both case-control studies reported greater risk reduction with 
proton pump inhibitors than with $\mathrm{H}_{2}$-receptor antagonists. In the first case-control study, the adjusted risk reduction was 0.32 (95\% CI: $0.22-0.51$ ) with proton pump inhibitors versus 0.40 (95\% CI: 0.19-0.73) with $\mathrm{H}_{2}$-receptor antagonists and, in the second case-control study, the adjusted risk reduction was 0.2 (95\% CI: $0.1-0.9)$ with omeprazole versus 0.5 (95\% CI: $0.2-1.2)$ with $\mathrm{H}_{2}$-receptor antagonists. ${ }^{52,53}$ The superiority of proton pump inhibitors over $\mathrm{H}_{2}$-receptor antagonists in the prevention of low-dose aspirin-related peptic ulcers was recently confirmed in a secondary prevention trial from Hong Kong. ${ }^{57}$ In this randomized, double-blind, controlled trial, 160 patients with aspirin-related peptic ulcers or erosions, with or without a history of bleeding, were randomly assigned to either high-dose famotidine (40 mg, morning and evening) or pantoprazole $(20 \mathrm{mg}$ in the morning and placebo in the evening). All patients continued to receive aspirin $80 \mathrm{mg}$ daily, and 130 patients $(81.1 \%)$ completed the study. At 48 weeks, 13 of 65 patients $(20 \%)$ in the famotidine group had recurrent dyspeptic or bleeding ulcers or erosions (95\% onesided CI for the risk difference $0.12-1.0$ ) compared with 0 of 65 patients $(0 \%)$ in the pantoprazole group $(P<0.0001$, 95\% one-sided CI for the risk difference 0.12-1.0). Gastrointestinal bleeding was significantly more common in the famotidine group (five of 65 patients; $7.7 \%$ ) than in the pantoprazole group ( 0 of 65 patients; $0 \%$ ), 95\% one-sided CI for the risk difference $0.02-1.0 ; P=0.03)$. Recurrent dyspepsia caused by ulcers or erosions was also significantly more common in the famotidine group (8 of 65 patients; $12.3 \%$ ) than in the pantoprazole group ( 0 of 65 patients; $0 \%$ ), with a $95 \%$ one-sided CI for the risk difference $0.06-1.0(P=0.003)$. No patients had ulcer perforation or obstructions. Therefore, in patients with low-dose aspirin-related peptic ulcers and continued aspirin use, pantoprazole was found to be superior to the high-dose $\mathrm{H}_{2}$-receptor antagonist, famotidine, in the secondary prevention of recurrent dyspeptic or bleeding ulcers and erosions. ${ }^{57}$

Whether or not aspirin therapy should be continued with concomitant proton pump inhibitors after endoscopic hemostatic therapy in patients who develop ulcer bleeding whilst on low-dose aspirin for cardiovascular or cerebrovascular disease was investigated further in a parallel, double-blind, randomized, placebo-controlled noninferiority trial, again from Hong Kong. ${ }^{58}$ A total of 156 patients with peptic ulcer bleeding whilst on low-dose aspirin therapy were randomly assigned to aspirin $80 \mathrm{mg}$ daily or placebo for eight weeks immediately after endoscopic therapy. All patients received a 72-hour infusion of pantoprazole followed by oral pantoprazole, and all patients completed follow-up.
At 30 days, endoscopically confirmed recurrent ulcer bleeding had occurred in $10.3 \%$ of the aspirin group and $5.4 \%$ of the placebo group (95\% CI for the difference, -3.6-13.4 percentage points). However, at eight weeks patients who received aspirin had lower all-cause mortality rates than patients who received placebo (1.3\% versus $12.9 \%$; 95\% CI for the difference, 3.7-19.5 percentage points) and lower mortality rates attributable to cardiovascular, cerebrovascular, or gastrointestinal complications than patients in the placebo group $(1.3 \%$ versus $10.3 \%$; $95 \%$ CI for the difference, $1.7-16.3$ percentage points). Therefore, among patients receiving low-dose aspirin therapy who had peptic ulcer bleeding, continued aspirin therapy may increase the risk of recurrent bleeding but potentially reduces mortality rates. However, the authors point out that the sample size was relatively small in this study, and that larger trials are needed to confirm the results. ${ }^{58}$

One potential drawback of combining low-dose aspirin with a proton pump inhibitor in patients with cardiovascular disease could be a reduction in antiplatelet effect, which has recently been found in a case-control study of 418 patients with coronary artery disease, 54 of whom received the combination of aspirin and a proton pump inhibitor. In this study, both platelet aggregation measured by whole blood aggregometry and platelet activation assessed by P-selectin were significantly higher in patients treated with a proton-pump inhibitor. ${ }^{59}$ However, this is the first study to find this effect. The data should be confirmed by other studies, as well as by studies of clinical endpoints.

\section{Clopidogrel}

Combination therapy with proton-pump inhibitors reduces the risk of aspirin-induced ulcer bleeding. However, compliance issues may limit the usefulness of combination therapy, especially in patients already subject to polypharmacy. An alternative strategy would be to replace aspirin with a less ulcerogenic antiplatelet drug. Clopidogrel is an adenosine diphosphate receptor antagonist that inhibits platelet activation induced by adenosine diphosphate. Clopidogrel has been shown to prevent ischemic events and has been approved by the Food and Drug Administration for treatment of vascular diseases. In the international, randomized, blinded CAPRIE (Clopidogrel versus Aspirin in Patients at Risk of Ischaemic Events) trial, 19,185 patients with symptomatic atherosclerosis (recent ischemic stroke, recent myocardial infarction, or symptomatic peripheral arterial disease) were randomized to receive clopidogrel $75 \mathrm{mg}$ daily or aspirin $325 \mathrm{mg}$ daily for 
1-3 years.$^{60}$ At a mean follow-up of 1.91 years, compared with aspirin, clopidogrel reduced the combined risk of ischemic stroke, myocardial infarction, or vascular death by $8.7 \%$ $(P=0.043)$. The overall incidence of hemorrhagic events did not differ between the treatment groups $(9.27 \%$ for clopidogrel versus $9.28 \%$ for aspirin; $P=0.98$ ). Gastrointestinal hemorrhage was significantly less frequent with clopidogrel than with aspirin (1.99\% for clopidogrel versus $2.66 \%$ for aspirin; $P<0.002)$. Overall, there were significantly fewer gastrointestinal adverse events with clopidogrel than with aspirin $(27.1 \%$ for clopidogrel versus $29.8 \%$ for aspirin; $P<0.001) .{ }^{60}$ Current guidelines recommend the use of clopidogrel for patients who are unable to take aspirin because of hypersensitivity or major gastrointestinal intolerance of aspirin. ${ }^{61}$ In two nearly identical randomized, controlled, double-blind trials from Hong Kong, clopidogrel was compared with aspirin plus esomeprazole for the prevention of recurrent bleeding from ulcers in high-risk patients. ${ }^{62,63}$ The first trial included $320 \mathrm{H}$. pylori-negative patients with ulcer bleeding whilst on low-dose aspirin. After the ulcers had healed, patients were randomly assigned to receive clopidogrel $75 \mathrm{mg}$ daily plus placebo twice daily or aspirin $80 \mathrm{mg}$ daily plus esomeprazole $20 \mathrm{mg}$ twice daily for 12 months. Recurrent ulcer bleeding occurred in 13 of 161 patients receiving clopidogrel (cumulative 12-month incidence $8.6 \%$; $95 \%$ CI: $4.1 \%-13.1 \%$ ) and in one of 159 patients receiving aspirin plus esomeprazole (cumulative 12-month incidence $0.7 \%$; $95 \% \mathrm{CI}:-2.0 \%$ ) (absolute difference $7.9 \%$; $95 \%$ CI for the difference $3.4 \%-12.4 \% ; P=0.001) .{ }^{62}$ The second trial included 170 patients with ulcer bleeding whilst on low-dose aspirin. After the ulcers had healed and H. pylori, if present, was eradicated, patients were randomly assigned to treatment with clopidogrel $75 \mathrm{mg}$ daily or esomeprazole $20 \mathrm{mg}$ and aspirin $100 \mathrm{mg}$ daily. After a median follow-up period of 52 weeks, nine patients in the clopidogrel group (cumulative incidence $13.6 \%$ ) versus 0 patients in the esomeprazole and aspirin group (cumulative incidence $0 \%$ ) developed recurrent ulcer complications (absolute difference 13.6\%; 95\% CI for the difference $6.3-20.9 \% ; P=0.002) .{ }^{63}$ From both trials we can conclude that, among patients with a history of aspirininduced ulcer bleeding, the combination of esomeprazole and aspirin is superior to clopidogrel in preventing recurrent ulcer complications. The exact mechanism by which clopidogrel causes recurrent ulcer bleeding is not known. Animal studies have shown that platelet adenosine diphosphate-receptor antagonists impair the healing of gastric ulcers by suppressing the release of platelet-derived growth factors. Clopidogrel may therefore induce recurrent ulcers in previously damaged gastric mucosa. ${ }^{62}$
In patients with acute coronary syndromes, current guidelines recommend the use of double antiplatelet therapy with both clopidogrel and aspirin. Double antiplatelet therapy is recommended for at least one month in unstable angina managed without intervention, for one year after non-STelevation myocardial infarction managed without intervention and for one year after ST-elevation myocardial infarction. In patients receiving placement of an intracoronary stent, double antiplatelet therapy may prevent stent thrombosis, an event associated with mortality rates of $20 \%-45 \%$. Current guidelines recommend double antiplatelet therapy for at least one month after implantation of a bare metal coronary artery stent and for one year or more after a drug-eluting stent. ${ }^{61}$ However, adding clopidogrel to aspirin has been shown to increase the risk of bleeding. ${ }^{64}$ In the previously mentioned population-based case-control study from Denmark, 1443 cases of serious upper gastrointestinal bleeding were compared with 57,720 age and gender-matched controls. Adjusted OR for upper gastrointestinal bleeding was 1.8 (95\% CI: 1.5-2.1) for low-dose aspirin, 1.1 (95\% CI: 0.6-2.1) for clopidogrel, but 7.4 (95\% CI: 3.5-15) for the combination of clopidogrel and aspirin. ${ }^{37}$ Gastroduodenal bleeding in these patients would have the clinical consequence of at least discontinuing clopidogrel therapy which, in turn, would increase the risk of myocardial infarction or stent thrombosis. Current guidelines therefore recommend concomitant use of proton pump inhibitors in patients with a history of gastrointestinal bleeding, when aspirin and clopidogrel are administered in combination or apart, to minimize the risk of recurrent gastrointestinal bleeding. ${ }^{61}$ However, some but not all, observational studies have shown that the use of proton pump inhibitors in patients taking clopidogrel is associated with an increased risk of reinfarction and death. In a population-based, nested case-control study among patients aged 66 years or older who commenced clopidogrel therapy following hospital discharge after treatment of acute myocardial infarction, cases were those readmitted with acute myocardial infarction within 90 days after discharge and event-free controls were matched on age, percutaneous coronary intervention, and a validated risk score. Among 13,636 patients prescribed clopidogrel, 734 cases and 2057 controls were identified. Current use of proton pump inhibitors was associated with an increased risk of reinfarction (adjusted OR, 1.27, $95 \%$ CI: $1.0-1.57) .{ }^{65}$

Clopidogrel is a prodrug that is converted in the liver to an active metabolite, which then irreversibly inhibits the platelet adenosine diphosphate receptor, consequently inhibiting adenosine diphosphate-induced platelet activation. Clopidogrel bioactivation is mediated by hepatic cytochrome $\mathrm{P} 450$ 
$2 \mathrm{C} 19$, and the activity of cytochrome P450 2C19 strongly influences the antiplatelet effect of clopidogrel. Emerging evidence suggests that some proton pump inhibitors can inhibit cytochrome P450 2C19 and may thereby negatively alter clopidogrel's pharmacokinetics. ${ }^{65}$ Several pharmacodynamic ex vivo studies measuring platelet-phosphorylated, vasodilator-stimulated phosphoprotein, expressed as a platelet reactivity index or adenosine diphosphate-induced platelet aggregation as markers for platelet aggregation, reported that omeprazole significantly decreased clopidogrel's inhibitory effect on platelets, but no difference was found for esomeprazole or lansoprazole, which do not inhibit cytochrome P450 2C19. ${ }^{66,67}$ Furthermore, the population-based nested casecontrol study mentioned earlier also found no association with pantoprazole for readmission with myocardial infarction (adjusted OR 1.02; 95\% CI: 0.70-1.47). ${ }^{65}$ Therefore, some international experts now recommend avoiding proton pump inhibitors with the highest potential for interaction with clopidogrel (ie, omeprazole) in patients with clopidogrel. However, because the presence of proton-pump inhibitors and clopidogrel in plasma is short-lived, separation by 12-20 hours should in theory prevent competitive inhibition of cytochrome P450 2C19 metabolism and minimize any potential clinical interaction. A proton-pump inhibitor may thus be given before breakfast and clopidogrel at bedtime, or a proton-pump inhibitor may be taken before dinner and clopidogrel at lunchtime. ${ }^{68}$

\section{Conclusion}

In summary, low-dose aspirin has proven itself for the secondary prevention of cardiovascular events in high-risk patients, ie, individuals with previous occlusive cardiovascular or cerebrovascular disease. There is no evidence supporting the prescription of low-dose aspirin as primary prevention in individuals at low absolute risk, in individuals with a single risk factor like diabetes mellitus, or in individuals with suspected asymptomatic occlusive vascular disease. Exact thresholds for treatment of individual patients at intermediate risk are not available, and whether the expected benefits in an individual outweigh the potential harm is to be judged by the treating physician. Furthermore, aspirin may have variable antiplatelet effects in individual patients, known as the phenomenon of "aspirin resistance", which implies that some individuals may not benefit from long-term treatment with low-dose aspirin. The use of aspirin, in the low doses prescribed for cardiovascular risk reduction, is also associated with upper gastrointestinal side effects, ranging from acute mucosal damage to ulcers and ulcer complications. The damaging effects of aspirin, as well as nonaspirin NSAIDs, on the gastrointestinal mucosa are mainly systemic, induced by inhibition of COX-1 and subsequent suppression of prostaglandin-mediated gastrointestinal defenses and blood platelet aggregation. The RR of gastrointestinal bleeding in aspirin users is in the range 1.3-3.2. ${ }^{28}$ Risk factors include a history of ulcers, age $\geq 60$ years, combined antithrombotic therapy, concurrent NSAIDs or corticosteroids, and infection with H. pylori. Appropriate strategies to minimize the risk of upper gastrointestinal bleeding in low-dose aspirin users include $H$. pylori eradication in patients with previous ulcers and use of gastroprotective agents, ie, misoprostol, highdose $\mathrm{H}_{2}$-receptor antagonists or proton-pump inhibitors. Clopidogrel may by unknown mechanisms induce recurrent ulcers in previously damaged gastric mucosa. Among patients with a history of aspirin-induced ulcer bleeding, the combination of esomeprazole and aspirin is superior to clopidogrel monotherapy in preventing recurrent ulcer complications. Adding clopidogrel to aspirin, as is recommended in protocols for the management of patients at high risk for occlusive coronary events, has been associated with an increased risk of bleeding. In these patients, the coprescription of a proton-pump inhibitor should be considered to reduce the gastrointestinal risk. However, because of a potential cytochrome P450 2C19-mediated interaction between proton-pump inhibitors and clopidogrel, the agent with the highest potential for interaction, ie, omeprazole, should either be avoided or dosages should be separated by at least 12 hours to preserve clopidogrel's inhibitory effect on platelets.

\section{Disclosure}

The authors declare no conflicts of interest in this work.

\section{References}

1. Hawkey CJ. COX-2 chronology. Gut. 2005;54:1509-1514.

2. Gibson AC. Oh willow, don’t weep. Available at: http://www.botgard. ucla.edu/html/botanytextbooks/eco nomicbotany/salix/. Accessed Jun 10, 2010.

3. Jones R. Nonsteroidal anti-inflammatory drug prescribing: Past, present and future. Am J Med. 2001;110:4S-7S.

4. Jack DB. One hundred years of aspirin. Lancet. 1997;350:437-439.

5. Dreser H. Pharmacologisches uber aspirin (acetylsalicyl saure). Pflugers Arch. 1899;76:306.

6. BayerAspirin. History of aspirin. 2010. Available at: http://www.bayeraspirin. com/pain/asp_history.htm. Accessed Jun 10, 2010.

7. Craven LL. Experiences with aspirin (acetylsalicylic acid) in the non-specific prophylaxis of coronary thrombosis. Miss Valley Med J. 1953;75:38-44.

8. O'Brien JR. Effects of salicylates on human platelets. Lancet. 1968;1: 779-783. 
9. Elwood PC, Cochrane AL, Burr ML, et al. A randomized controlled trial of acetyl salicylic acid in the secondary prevention of mortality from myocardial infarction. Br Med J. 1974;1:436-440.

10. Antithrombotic Trialists' Collaboration. Collaborative meta-analysis of randomised trials of antiplatelet therapy for prevention of death, myocardial infarction, and stroke in high risk patients. BMJ. 2002; 324:71-86.

11. Chen ZM, Sandercock P, Pan HC, et al. Indications for early aspirin use in acute ischemic stroke: A combined analysis of 40000 randomized patients from the Chinese Acute Stroke Trial and the International Stroke Trial. On behalf of the CAST and IST collaborative groups. Stroke. 2000;31:1240-1249.

12. Baigent C, Blackwell L, Collins R, et al; Antithrombotic Trialists' (ATT) Collaboration. Aspirin in the primary and secondary prevention of vascular disease: Collaborative meta-analysis of individual participant data from randomised trials. Lancet. 2009;373:1849-1860.

13. Zhang C, Sun A, Zhang P, et al. Aspirin for primary prevention of cardiovascular events in patients with diabetes: A meta-analysis. Diabetes Res Clin Pract. 2010;87:211-218.

14. Pignone M, Alberts MJ, Colwell JA, et al. Aspirin for primary prevention of cardiovascular events in people with diabetes. A position statement of the American Diabetes Association, a scientific statement of the American Heart Association, and an expert consensus document of the American College of Cardiology Foundation. Circulation. 2010;121:2694-2701.

15. Fowkes FG, Price JF, Stewart MC; Aspirin for Asymptomatic Atherosclerosis Trialists. Aspirin for prevention of cardiovascular events in a general population screened for a low ankle brachial index: A randomized controlled trial. JAMA. 2010;303:841-848.

16. Berger JS. Aspirin as preventive therapy in patients with asymptomatic vascular disease. JAMA. 2010;303:880-882.

17. Berger JS, Krantz MJ, Kittelson JM, Hiatt WR. Aspirin for the prevention of cardiovascular events in patients with peripheral artery disease: A meta-analysis of randomized trials. JAMA. 2009;301:1909-1919.

18. Krasopoulos G, Brister SJ, Beattie WS, Buchanan MR. Aspirin "resistance" and risk of cardiovascular morbidity: Systematic review and meta-analysis. BMJ. 2008;336:195-198.

19. Ajjan R, Storey RF, Grant PJ. Aspirin resistance and diabetes mellitus. Diabetologia. 2008;51:385-390.

20. Derry S, Loke YK. Risk of gastrointestinal haemorrhage with long term use of aspirin: Meta-analysis. BMJ. 2000;321:1183-1187.

21. Lanas A, Perez-Aisa MA, Feu F, et al; Investigators of the Asociación Española de Gastroenterología (AEG). A nationwide study of mortality associated with hospital admission due to severe gastrointestinal events and those associated with nonsteroidal anti-inflammatory drug use. Am J Gastroenterol. 2005;100:1685-1693.

22. Douthwaite AH, Lintott SAM. Gastroscopic observation of the effect of aspirin and certain other substances on the stomach. Lancet. 1938;2:1222-1225.

23. Vonkeman HE, van de Laar MA. Nonsteroidal anti-inflammatory drugs: Adverse effects and their prevention. Semin Arthritis Rheum. 2010;39:294-312.

24. Manes G, Balzano A, Marone P, Lioniello M, Mosca S. Appropriateness and diagnostic yield of upper gastrointestinal endoscopy in an open-access endoscopy system: A prospective observational study based on the Maastricht guidelines. Aliment Pharmacol Ther. 2002;16:105-110.

25. Yeomans ND, Lanas AI, Talley NJ, et al. Prevalence and incidence of gastroduodenal ulcers during treatment with vascular protective doses of aspirin. Aliment Pharmacol Ther. 2005;22:795-801.

26. Kelly JP, Kaufman DW, Jurgelon JM, Sheehan J, Koff RS, Shapiro S. Risk of aspirin-associated major upper-gastrointestinal bleeding with enteric-coated or buffered product. Lancet. 1996;348:1413-1416.

27. Wallace JL. Nonsteroidal anti-inflammatory drugs and gastroenteropathy: The second hundred years. Gastroenterology. 1997;112: 1000-1016.
28. Shiotani A, Kamada T, Haruma K. Low-dose aspirin induced gastrointestinal diseases: Past, present, and future. J Gastroenterol. 2008:43:581-588.

29. Graham DY, Smith JL, Dobbs SM. Gastric adaptation occurs with aspirin administration in man. Dig Dis Sci. 1983;23:1-6.

30. Geall MG, Phillips SF, Summerskill WH. Profile of gastric potential difference in man. Effects of aspirin, alcohol, bile, and endogenous acid. Gastroenterology. 1970;58:437-443.

31. Laine L, Maller ES, Yu C, Quan H, Simon T. Ulcer formation with lowdose enteric-coated aspirin and the effect of COX-2 selective inhibition: A double blind trial. Gastroenterology. 2004;127:359-402.

32. Weisman SM, Graham DY. Evaluation of the benefits and risks of low-dose aspirin in the secondary prevention of cardiovascular and cerebrovascular events. Arch Intern Med. 2002;162:2197-2202.

33. McQuaid KR, Laine L. Systematic review and meta-analysis of adverse events of low-dose aspirin and clopidogrel in randomized controlled trials. Am J Med. 2006;119:624-638.

34. Sorensen HT, Mellemkjaer L, Blot WJ, et al. Risk of upper gastrointestinal bleeding associated with use of low-dose aspirin. Am J Gastroenterol. 2000;95:2218-2224.

35. Singh G, Rosen Ramey D. NSAID-induced gastrointestinal complications: The ARAMIS perspective - 1997. J Rheumatol Suppl. 1998;51:8-16.

36. US Preventive Services Task Force. Aspirin for the prevention of cardiovascular disease: U.S. Preventive Services Task Force recommendation statement. Ann Intern Med. 2009;150:396-404.

37. Hallas J, Dall M, Andries A, et al. Use of single and combined antithrombotic therapy and risk of serious upper gastrointestinal bleeding: Population based case-control study. BMJ. 2006;333:726.

38. Lanas A, Scheiman J. Low-dose aspirin and upper gastrointestinal damage: Epidemiology, prevention and treatment. Curr Med Res Opin. 2007;23:163-173.

39. Bhatt DL, Scheiman J, Abraham NS, et al; American College of Cardiology Foundation Task Force on Clinical Expert Consensus Documents. ACCF/ACG/AHA 2008 expert consensus document on reducing the gastrointestinal risks of antiplatelet therapy and NSAID use: A report of the American College of Cardiology Foundation Task Force on Clinical Expert Consensus Documents. Circulation. 2008;118:1894-1909.

40. Lanas A, García-Rodríguez LA, Arroyo MT, et al; Asociación Española de Gastroenterología. Risk of upper gastrointestinal ulcer bleeding associated with selective cyclo-oxygenase-2 inhibitors, traditional nonaspirin non-steroidal anti-inflammatory drugs, aspirin and combinations. Gut. 2006;55:1731-1738.

41. Steinhubl SR, Bhatt DL, Brennan DM, et al; CHARISMA Investigators. Aspirin to prevent cardiovascular disease: The association of aspirin dose and clopidogrel with thrombosis and bleeding. Ann Intern Med. 2009;150:379-386.

42. Hunt RH, Bazzoli F. Should NSAID/low-dose aspirin takers be tested routinely for $H$. pylori infection and treated if positive? Implications for primary risk of ulcer and ulcer relapse after initial healing. Aliment Pharmacol Ther. 2004;19:9-16.

43. Chan FK, Graham DY. Prevention of non-steroidal anti-inflammatory drug gastrointestinal complications - review and recommendations based on risk assessment. Aliment Pharmacol Ther. 2004;19: 1051-1061.

44. Huang JQ, Sridhar S, Hunt RH. Role of Helicobacter pylori infection and non-steroidal anti-inflammatory drugs in peptic-ulcer disease, a meta-analysis. Lancet. 2002;359:14-22.

45. Vergara M, Catalán M, Gisbert JP, Calvet X. Meta-analysis, role of Helicobacter pylori eradication in the prevention of peptic ulcer in NSAID users. Aliment Pharmacol Ther. 2005;21:1411-1418.

46. Lanas A, Fuentes J, Benito R, Serrano P, Bajador E, Sáinz R. Helicobacter pylori increases the risk of upper gastrointestinal bleeding in patients taking low-dose aspirin. Aliment Pharmacol Ther. 2002;16:779-786. 
47. Chan FK, Chung SC, Suen BY, et al. Preventing recurrent upper gastrointestinal bleeding in patients with Helicobacter pylori infection who are taking low-dose aspirin or naproxen. $N$ Engl J Med. 2001;344:967-973.

48. Lai KC, Lam SK, Chu KM, et al. Lansoprazole for the prevention of recurrences of ulcer complications from long-term low-dose aspirin use. N Engl J Med. 2002;346:2033-2038.

49. Rostom A, Dube C, Wells G, et al. Prevention of NSAID-induced gastrointestinal ulcers. Cochrane Database Syst Rev. 2002;2:CD002296.

50. Donnelly MT, Goddard AF, Filipowicz B, Morant SV, Shield MJ, Hawkey CJ. Low-dose misoprostol for the prevention of low-dose aspirin-induced gastroduodenal injury. Aliment Pharmacol Ther. 2000;14:529-534.

51. Taha AS, McCloskey C, Prasad R, Bezlyak V. Famotidine for the prevention of peptic ulcers and oesophagitis in patients taking low-dose aspirin (FAMOUS): A Phase III, randomised, double-blind, placebocontrolled trial. Lancet. 2009;374:119-125.

52. Lanas A, García-Rodríguez LA, Arroyo MT, et al; Investigators of the Asociación Española de Gastroenterología (AEG). Effect of antisecretory drugs and nitrates on the risk of ulcer bleeding associated with nonsteroidal anti-inflammatory drugs, antiplatelet agents, and anticoagulants. Am J Gastroenterol. 2007;102:507-515.

53. Lanas A, Bajador E, Serrano P, et al. Nitrovasodilators, low-dose aspirin, other nonsteroidal anti-inflammatory drugs, and the risk of upper gastrointestinal bleeding. N Engl J Med. 2000;343:834-839.

54. Simon B, Elsner H, Müller P. Protective effect of omeprazole against low-dose acetylsalicylic acid. Endoscopic controlled double-blind study in healthy subjects. Arzneimittelforschung. 1995;45:701-703.

55. Müller P, Fuchs W, Simon B. Studies on the protective effect of lansoprazole on human gastric mucosa against low-dose acetylsalicylic acid. An endoscopic controlled double-blind study. Arzneimittelforschung. 1997;47:758-760.

56. Yeomans N, Lanas A, Labenz J, et al. Efficacy of esomeprazole (20 mg once daily) for reducing the risk of gastroduodenal ulcers associated with continuous use of low-dose aspirin. Am J Gastroenterol. 2008;103:2465-2473.

57. $\mathrm{Ng} \mathrm{FH}$, Wong SY, Lam KF, et al. Famotidine is inferior to pantoprazole in preventing recurrence of aspirin-related peptic ulcers or erosions. Gastroenterology. 2010;138:82-88.

58. Sung JJ, Lau JY, Ching JY, et al. Continuation of low-dose aspirin therapy in peptic ulcer bleeding: A randomized trial. Ann Intern Med. 2010;152:1-9.
59. Würtz M, Grove EL, Kristensen SD, et al. The antiplatelet effect of aspirin is reduced by proton pump inhibitors in patients with coronary artery disease. Heart. 2010;96:368-371.

60. Harker LA, Boissel JP, Pilgrim AJ, Gent M. Comparative safety and tolerability of clopidogrel and aspirin: Results from CAPRI. CAPRIE Steering Committee and Investigators. Clopidogrel versus aspirin in patients at risk of ischaemic events. Drug Saf. 1999;21: 325-335.

61. Anderson JL, Adams CD, Antman EM, et al; American College of Cardiology. American Heart Association Task Force on Practice Guidelines (Writing Committee to Revise the 2002 Guidelines for the Management of Patients With Unstable Angina/Non ST-Elevation Myocardial Infarction); American College of Emergency Physicians; Society for Cardiovascular Angiography and Interventions; Society of Thoracic Surgeons; American Association of Cardiovascular and Pulmonary Rehabilitation; Society for Academic Emergency Medicine. ACC/AHA 2007 guidelines for the management of patients with unstable angina/non-ST-elevation myocardial infarction. Circulation. 2007;116:e138-e304.

62. Chan FK, Ching JY, Hung LC, et al. Clopidogrel versus aspirin and esomeprazole to prevent recurrent ulcer bleeding. $N$ Engl J Med. 2005;352:238-244.

63. Lai KC, Chu KM, Hui WM, et al. Esomeprazole with aspirin versus clopidogrel for prevention of recurrent gastrointestinal ulcer complications. Clin Gastroenterol Hepatol. 2006;4:860-865.

64. Yusuf S, Zhao F, Mehta SR, Chrolavicius S, Tognoni G, Fox KK. Clopidogrel in unstable angina to prevent recurrent events trial investigators. Effects of clopidogrel in addition to aspirin in patients with acute coronary syndromes without ST-segment elevation. $N$ Engl J Med. 2001;345:494-502.

65. Juurlink DN, Gomes T, Ko DT, et al. A population-based study of the drug interaction between proton pump inhibitors and clopidogrel. CMAJ. 2009;180:713-718

66. Gilard M, Arnaud B, Cornily JC, et al. Influence of omeprazole on the antiplatelet action of clopidogrel associated with aspirin, the randomized, double-blind OCLA (Omeprazole CLopidogrel Aspirin) study. J Am Coll Cardiol. 2008;51:256-260.

67. Siller-Matula JM, Spiel AO, Lang IM, Kreiner G, Christ G, Jilma B. Effects of pantoprazole and esomeprazole on platelet inhibition by clopidogrel. Am Heart J. 2009;157:148.e1-e5.

68. Laine L, Hennekens C. Proton pump inhibitor and clopidogrel interaction, fact or fiction? Am J Gastroenterol. 2009;105:34-41.
Drug, Healthcare and Patient Safety

\section{Publish your work in this journal}

Drug, Healthcare and Patient Safety is an international, peer-reviewed open-access journal exploring patient safety issues in the healthcare continuum from diagnostic and screening interventions through to treatment, drug therapy and surgery. The journal is characterized by the rapid reporting of reviews, original research, clinical, epidemiological and

\section{Dovepress}

post-marketing surveillance studies, risk management, health literacy and educational programs across all areas of healthcare delivery. The manuscript management system is completely online and includes a very quick and fair peer-review system. Visit http://www.dovepress.com/ testimonials.php to read real quotes from published authors. 